Оригинални научни рад

331.105.2-057.16:347.51

doi:10.5937/zrpfns52-18280

Henriett J. Rab, Ph.D., Associate Professor

University of Debrecen

Faculty of Law

Department of Agricultural, Environmental and Labor Law

rab.henriett@law.unideb.hu

Bianka T. Sütö, Ph.D., Student

University of Debrecen

Faculty of Law

Marton Géza Doctoral School of Legal Studies

biankamathe@gmail.com

\title{
THE ECONOMIC ASPECT OF THE RESPONSIBILITY OF EXECUTIVE EMPLOYEES*
}

Abstact: Several new challenges emerging in labour law and in the labour market are based on societal and economic circumstances. These changes seem natural in a way; on the one hand, employers have their own economic interests and whole societies will shape according to the new frameworks of employment. On the other hand, workers do not remain the same either; more and more flexible, more digitalised, more balanced working conditions are on the agenda meanwhile the traditional social side of labour law regulations is withdrawing. And in an aspect we focused on the executive employees because they are between the employer and the employee position. They need do their job to manage well the organisation, but they need to think as their employees and organise the work in that way. That's why we think the executive employees position is interesting in labour law and in economic aspect.

Keywords: labour law - labour market - executive employee - economic expectation - labour relation.

* The paper was created within the framework of a research and education development project at the University of Debrecen under the program of Hungarian Ministry of Justice aiming to increase the quality of the education of law students 


\section{INTRODUCTION}

The starting point for our study is the joint investigation of both the legal and the economic dilemmas of the responsibilities of senior employees. Among the responsibilities of senior employees, the coexistence of civil law and labor law responsibilities is causing an interpretational issue, which further tangles with the regulatory intent of the two legal fields that is not necessarily the same. In the field of economics, the identification of the executive with the organization, the display of economic interests and, last but not least, the question of market justice means the area to be solved.

The novelty of the study is that the examination of the legal framework has not yet covered these aspects. Following the re-codification of the Civil Code (Act V of 2013) and the Labor Code (Act I of 2012), the issue of conflicts of law was published as a fundamental issue in the legal interpretation. However, when it was being resolved, the authors did not take into account the needs of economics despite the fact that executive employees represent a significant economic potential. Several domestic and foreign works of scholars dealing with labor law establishes the foundation, that labor law and the situation of market players, hence the economic expectations can not be separated from each other. Nevertheless, the question of the liability of executive employees is not even appears at a principal level. We would like to fill this gap with the contents of this study, so those elements and points of view that have not been analyzed yet so far can be presented and taken into consideration as the issue is examined.

The study is therefore grouped around the following major subjects:

1. The legal status of executive employees, dilemas of the regulation

2. Presentation of the theories of business management, including the remuneration of business executives and economic success and justice.

3. Analisys of the theories of the labor law, that support the consideration of market demands, from the perspective of executive employees.

4. Assessing legal regulations in the light of economic expectations.

\section{THE LEGAL STATUS OF EXECUTIVE EMPLOYEES}

The general problem of the legal regulations of executive employees is the co-existence and application of the non-matching regulatory logic and solution of the Labor Code and the Civil Code. From some perspectives, this problem can not be resolved, ${ }^{1}$ while from other perspectives it is only apparent. ${ }^{2}$ The basis of the

${ }^{1}$ It is particularly difficult to resolve this issue by for the jurisdiction of the courts, since it is not irrelevant when and where the the labor courts have jurisdiction is concerned, also what are the issues that are already within the scope of the internal or external relations of the company and thus fall under the jurisdiction civil courts.

${ }^{2}$ In that respect, it is apparent that the Labor Code as lex specialis applies to the executive officer if employed in an employment relationship. 
conflict lies in the fact that the legal status of an executive officer can be established within more legal relationships, ${ }^{3}$ thus the governing rule of legal relationships is also reflected in the employment. As long as this underlying relationship exists between the civil law framework (personal services contract, works contract), the formula is relatively straightforward, but as soon as the employment is made under an employment relationship ${ }^{4}$, we already find ourselves in different legal regulatory considerations and demands.

The term "executive officer" that appears in civil and corporate law is intended to represent a natural person providing operational function of companies with legal personality. Thus, the corporate law approach does not pay much attention to regulate the labor law background associated with the performance of this natural person. According to György Kiss, this position is obvious, since the legal status of the executive officer is not determined by the form of the employment, so whether it is an employment relationship or a personal service contract, but the fact that the executive officer accepts that he or she is elected or appointed by the legal decision-making body of the legal person. ${ }^{5}$ Judit Bartha - Major Tünde Majoros distinguishes the mandate or employment relationship that appears behind the status of a an executive employee as an accessory. ${ }^{6}$ This opinion is supported by the fact that the legal status of the executive officer is established regardless if the contract for the legal relationship of employment is actually concluded, if the chief executive accepts the election or appointment of the decision-making body.

The coexistence of civil law and labor law regarding the regulation of the executive officers can be identified at several fields. Thus, for example, labor law is particularly interesting when Section 20 (2) of the Labor Code allows the employer to authorize a person who is not employed by the employer in an employment relationship to exercise employer's powers. ${ }^{7}$ By this, labor law recognizes the existence of the opportunity to employ the executive officers through a civil law relationship where the executives fill the position through a personal service contract. However, if the executive officer, who is entitled to exercise the employer's rights, is not employed with an employment contract, will not be an employee under the labor law regulations and thus special labor law regulations shall not be applied. That is, a person with a purely civil law status becomes a practitioner of labor law. We can see a reversed situation when an employee of the employer is

\footnotetext{
${ }^{3}$ György Kiss, “A vezető tisztségviselö felelőssége“, A vezetö tisztségviselö felelössége munkajogi szempontból (eds. Csehi Zoltán, Szabó Marianna), Wolters Kluwer, Budapest, 2015, 149.

${ }^{4}$ For more on employment relationship see: S. Jašarević, Labour Relation-Tendencies in the practice and in the Regulations, Collected papers - Novi Sad Faculty of Law, No. 3/2013, 237-255.

${ }^{5}$ Gy. Kiss, 149., 155.

${ }^{6}$ Judit Bartha, Tünde Majoros,’A vezető tisztségviselö társasággal szembeni és harmadik személynek okozott károkért való felelősségének neuralgikus kérdései”, Miskolci Jogi Szemle, 2015/2., 6 .
}

${ }^{7}$ Gy. Kiss, 160 
appointed as a manager, however, the consideration of this question is more complicated from the point of view of civil law, so we will discuss it later on.

The separation of civil law and labor law, despite the coexistence described previously, is justified by the fact that the legal person, as a business entity is established primarily for the purposes of carrying out economic activities and, as such, wishes to engage in market transactions. The security of business world, regardless of the employment, expects the management of the external affairs of a legal person. In addition to the executive officers, employees who are not considered as executive officers may also perform the duties of representing a legal person if the legal person authorizes them to do so in writing. Their responsibilities in this case are in accordance with the general rules of responsibility in terms of labor law, which is, in this case elevated to a higher level by the corporate law / civil liability, that is, the rules of civil liability shall also be applied concerning their responsibility. ${ }^{8}$

As an anticipation of our thoughts that we intend to formulate in the present study later on, we would like to highlight that the responsibility expected externally and the management of the company's internal affairs are exacty the factors that provide the necessity of a more flexible system of liability being more adaptable to these circumstances. From the point of view of labor law, this means the right job performance "in the position of an employer", but the increased accountability for the company's affairs is not represented. However, in several theories of the public economy, ${ }^{9}$ it is emphasized that the personal interest of the business leaders, particularly at large corporations come to the forefront against the demands of the company. In our view, however, labor law liability does not constitute a sufficient protection in these situations. While, therefore, it may cause difficulties when enforcing labor law liability that different responsibilities emerge as far as the nature of the work is concerned, and labor law liability may also be in conflict with the civil law rules, this responsibility network may be forward-looking for the sake of economic life.

Returning to the dual status of the executive officers and executive employees, that the result of the diversity of the legal relationship of employment linked to the executive status and position in company law, it is required to establish the consistency or hierarchy of the different regulations. In our view, the biggest disturbance is due to the fact that the executives - both in accordance with the labor law and the civil law - act under a double expectation system. An executive employee is simultaneously employed in the position of an employee in an employment relationship depending on the employer and in many cases performs the employer's role as the representative of the employer. As an executive officer,

${ }^{8}$ Lívia Mihovics, "A vezető tisztségvisleő felelősségére irányadó szabályok az új Ptk.-ban", Számvitel, Pénzügy, Adózás, 2014/4., 97.

${ }^{9}$ See e. g. later on Wojciech Kopczuk, James Pierson, John H. Cochrane, Thomas Piketty, Kevin J. Murphy, Jesse M. Fried 
pursuant to Section 3:21 of the Civil Code, is entitled to make decisions on the management of legal persons (that do not constitute the competency of the owners or founders), but can exercise its executive activities only in such a way as to act in accordance with the interests of the legal person.

The executive employee has a special status in labor law, and is employed in a kind of atypical employment relationship, where the employee's side is the subject-matter of the specialty. The atipicity of the executive employment relationship is that not all executive officers are employed under an employment relationship and that not all executive employees are considered to be executive officers at the same time, furthermore, it is a fundamental specialty that the executive employment contract may differ from the whole Part Two of the Labor Code. ${ }^{10}$ The atypical nature of the legal relationship may also be manifested by the fact that an executive employee is in many cases is the owner of the company, and, as an executive officer exercises employer's rights towards the other employees of the employer.

The atypical nature of executive employment relationships can aso be modeled from the perspective of HR. Thus, the status of executive employees is extraordinary as it is based on a special relationship of trust between the executive employee and the team that it controls. An executive employee must have a number of competences that makes her or him capable to represent the interests of the company and to guide employees accordingly. Thus, the executive employer shall be able to develop a proper business policy, coordinate complex tasks, manage members of the organization for the sake of good corporate goals, and last but not least to define core business goals. In addition, however, its most important task is to make efficient and profit-making choices for the company's competitiveness. ${ }^{11}$

In the light of the above, we can say that the executive officer is the person who is - as an individual - can be the determinant of a company, both for its external and internal environment. Perhaps it would be an exaggeration to say that they must be irreprovable, but it is certain that as being an organizational leader and as a representative of the interests of the owners, it should be an unconditional requirement to represent prestige and high moral values for both the inner and the outer environment from both the perspective of business and the private life. ${ }^{12}$

An addictional characteristic of the atypicality of the executive officers is that there is not an exact legal definition of the activities of the executive officers both domestic and international levels, despite the fact that - with the widespread of the transnational corporations- it is used every day. The Labor Code does not

${ }^{10}$ Zoltán Bankó, Jácint Ferencz, Atipikus munkaviszonyok, Wolters Kluwer, Budapest, 2015, 80.

${ }^{11}$ Rita Ráczki, “A vezetés természetének átalakulása”, Munkaügyi Szemle/2009-4.

12 Tamás Prugberger, "A vezető állású alkalmazottak jogiszonyának egyes kérdései a gazdasági munka világában”, Jogtudományi Közlöny, 1999. május 
regulate the definition of the "management contract" even though in general terms the word "manager" is commonly used instead of the complex concept of the executive employee.

Even from the perspective of the labor law, it is not easy to determine the status of executive employees, because several dilemmas emerge regarding its conceptual elements that arise from the substantive legal regulations. Below we will review them briefly:

\subsection{Who is an executive employer and its deputy?}

According to Section 208 (1) of the Labor Code, Executive employee' shall mean the employer's chief executive officer, and any other person under his or her direct supervision and authorized - in part or in whole - to act as his or her deputy. The chief executive officer of the employer, as an executive officer, can be employed in an employment relationship or in a personal service contract under the civil law as I have already outlined above. the question may arise whether the executive officer employed in the civil law relationship of personal services contract is recognized by the labor law as an employee in an employment realtionship? In my view, the answer to this question is reassuring if we consider it not possible, because of the contractual nature of the employment relationship, the will to engage into contract is essential. In case of an opposite explanation, the choice to choose between an employment relationship or a personal services contract, that is offered by civil law pursuant to Article 3:112. § (1) of the Civil Code, would become idle.

Regarding the deputy of the chief executive officer, it is easier to designate the people involved, since the Labor Code clearly requiresan employment relationship. The problem in this case is the scope of the deputy activities, where the Labor Code allows the employee to be recognized as an executive employee in the case of a partial substitution if he is in subordinate relationship with the manager. In order to determine whether the tasks considered deputy activities depend on if the tasks performed are considered to be a direct substitution the chief executive. ${ }^{13}$

\subsection{What position has a considerable importance? What position is highly confidential?}

Section 208 (2) of the Labor Code extends the employer's opportunities to recognize an employee as an executive employee as an executive employee. Thus, by the mutual agreement of the parties, the employment contracts itself may invoke the provisions on executive employees if the employee is in a position considered

${ }^{13}$ Gyula Berke, György Kiss, Kommentár a munka törvénykönyvéhez, Wolters Kluwer, Budapest, 2014, 597. 
to be of considerable importance from the point of view of the employer's operations, or fills in a highly confidential position, and his salary reaches seven times the mandatory minimum wage. The uncertainty of the definition, that requires an interpretation, is the position with considerable importance and the highly confidential position. Based on the Ministerial Justificatin of the Labor Code, to determine whether an activity has a considerable importance all the circumstances of the case, primarily the employer's operation and organizational structure shall be examined. If the job is highly confidential, it requires a much greater loyalty and reliability to accomplish it.

\subsection{Who is a manager?}

The options provided in the Labor Code to create executive positions are also supported by civil law, when Section 3:113. $\S$ of the Civil Code allows the company's supreme body to appoint one or more managers to assist the executive officers in their work. The manager is an intermediate status between the executive officer and the executive employee. ${ }^{14}$ The company manager shall be an employee of the company, but it is not a requirement to be qualified as an executive employee undr labor law. ${ }^{15}$ Under company law regulations, however, the company manager is not the executive officer of the company. In this complex legal situation, which is full of controversial and partially overlapping regulations, the question of liability requires a separated interpretation. The institution of liability serves the purpose of internalizing the negative consequences of the decisions for the chief executive, thus, to make him bear the consequences of his conduct of executive activities even in the absence of ownership interests. ${ }^{16}$ Under the applicable Section 209. § (5) of the Labor Code, an executive employee shall be subject to full liability for damages caused by negligence. Otherwise, the liability of the executive employees is in accordance with the general labor law liability, adding that the parties may deviate from the statutory rules with their agreement. As an exception, the liability for damages caused intentionally shall not be limited or excluded. ${ }^{17}$ The liability of the employees for damages in the

${ }^{14}$ Gy. Kiss 165 .

${ }^{15}$ Of course, this rule does not rule out the option for the companies to classify their employee authorized with managerial rights as an executive employee under Section 208 (1) or even (2) of the Labor Code, , provided that they meet the stipulated labor law standards. See further: Miskolcziné Juhász Boglárka, „A vezető állású munkavállalókra vonatkozó munkajogi szabályozás változása - a jogértelmezési problémák a gyakorlatban”, Ügyészek Lapja, 2014/1. szám, 32.

${ }^{16}$ András Kisfaludi, “(L)ex Cathedra et Praxis, Ünnepi kötet Lábady Tamás 70. születésnapja alkalmából” A jogi személy vezető tisztségviselöinek felelössége az új Polgári Törvénykönyvben (eds. Csehi Zoltán, Koltay András, Landi Balázs, Pogácsás Anett), Pázmány Press, Budapest, 2014, 309.

${ }^{17}$ Gy. Berke, Gy. Kiss, 602. 
new Labor Code is basically stricter than it was in the previous regulation. ${ }^{18} \mathrm{Re}-$ gadring the the liability of the employees, the Labor Code refers to the Section 6:518-534. § of the Civil Code. As a consequence, of this, in the case of executive employees, rules of the civil law liability appear as underlying regulations. However, contradictions have emerged from the different regulatory logic as the date of predictability. ${ }^{19}$

By any means, it is a result that the rules of liability of executive officers have been brought to a mutual foundation regarding the application of labor law and civil law. ${ }^{20}$ However, the expectations towards the executive officers regarding theot corporate law liability in our opinion are unjustified compared to the labor law liability. Businesses life determines the liability of corporate executives based on the level of prudency and diligence in foreign company law as well, ${ }^{21}$ and yet there is not a reasonable assurance that the interests of the interests of the executive officer and the interests of the company operations are pointing into the same direction and lead to the same result. ${ }^{22}$ The applicable regulations of the Civil Code in force do not use this wording, instead, it says that the executive officer shall be held liable for damages caused to the legal person resulting from his management activities in accordance with the provisions on liability for damages for loss caused by non-performance of an obligation. There is a similar relationship between the employer and the executive employee, so the basis of the regulations regarding the liability are the rules of non-performance of an obligation. In our view, the inconcsistency of the regulation is coming from that under the new regulations the executive employer is no longer liable only if the damages were caused in connection with the executive activities and if it was caused against the other party of the employment relationship, that is, the employer. Despite this, Section 3:24. $\S$ of the Civil Code prescribes the application of the provisions of

${ }^{18}$ According to Zoltán Rácz, the liability of the „subordinate” employees quasi became as heavy it is according tot he regulations on the executive employees. In: Zoltán Rácz: „A vezető állású munkavállalókra vonatkozó speciális összeférhetetlenségi szabályok.” Jogi iránytü. 2011/4. 2.

${ }^{19}$ According to Section 179 (4) of the Labor Code, the time of the damage is relevant for predictability. However, Section 6:142. § of the Civil Code links the measure of predictability to the time of the conclusion of the contract. The derogation can be solved by the lex specialis principle for the benefit of the Labor Code. In: Bodzási Balázs, "A jogi személyek körében felmerülő felelősségi kérdésekről, különös tekintettel a vezető tisztségviselőkre”, Gazdaság és Jog, 2013/6., 12., see also this issue examined further in details from the election and the conclusion of the employment contract in: J.Bartha, T. Majoros 7-9.

${ }^{20}$ According to Boglárka Miskolcziné Juhász there is a coherence between these regulations, however, application, jurisdiction and interpretation of the law revealed several problems that is to be solved. In: M. J. Boglárka, 41.

${ }^{21}$ Tibor Nochta: A vezető tisztségviselők magánjogi felelősségének mércéjéről és irányairól az új Ptk. alapján, Gazdaság és Jog, 2013/6., 3.

${ }^{22}$ See the nowadays popular theory of Thomas Pikkety in: Thomas Piketty, A töke a XXI. században, Kossuth Kiadó, Budapest, 2015. 
the non-performance of the obligations regarding the damages caused to the legal persons, that covers exactly the same area, not from a labor law but from a civil law perspective. ${ }^{23}$

From the point of view of the liability of executive officers, the corporate law right to issue a hold-harmless statement shall not be ignored, that is according to the Ministerial Justification of th Civil Code is "a decision that acknowledges the appropriateness of the management activities of the executive officer". Section 3:117. § (1) of the Civil Code states that if the hold-harmless statement was issued the company may bring action against the executive officer on the grounds of breaching management obligations in a claim for damages if the facts and information underlying the hold-harmless statement proved to be false or incomplete.

In the interpretation of the hold harmless statement, it should not be overlooked that, regarding this study, this legal institution serves the purpose to screen the inadquate executive activities, and that it seems to be a suitable solution for the executive officer to transfer the liability to the decision-making body. However, the institution of the hold harmless statement shall not be considered as a simple limitation of liability, but merely an acknowledgement that the activities of the management are appropriate. ${ }^{24}$

Throught the rules of the hold armless statement we can face the issue that the guaranteeing role of the right often leads to solutions that are in conflict with or contrary to market interests. From the point of view of our study, we would highlight the the importance of the hold harmless statement from the perspective of the exclusion of decision-making and management responsibility, which could lead to a reduction in corporate and market efficiency, despite this, law provides the right to individual legal protection in the hands of executive officers without the consideration of market interests. As executive officers are quite sensitive to the risks associated with their activities, they are looking for solutions that can be used to provide security against these risks. ${ }^{25}$

\section{DETERMINING THE ROLE OF EXECUTIVE OFFICERS REGARDING MARKET AND ECONOMIC CONSIDERATIONS}

Today, the biggest challenge for corporate governance and leadership is the increased economic risk taking, which is inevitable in the course of decision-making. The primary business expectation of management work is to enforce efficiency

${ }^{23}$ The issue gets more complicated by highlighting the fact that the regulations on civil law liability are also dispositive regarding the executive officials. See in details: Gy. Kiss, 184-185.

${ }^{24}$ Gy. Berke, Gy. Kiss, 601.

${ }^{25}$ A. Kisfaludi, 327. 
and effectiveness criteria in our time. The merging objective of the company's management is to strive for a greater profit. ${ }^{26}$

Our related hypothesis is that the income of top managers has grown drastically in recent decades. This phenomenon is analyzed in many specialized literatures. One of the most famous work on this subject is, perhaps, the already mentioned book of the French economist, Thomas Piketty, titled "Capital in the Twenty-First Century “. Piketty's work summarizes the features and the theoretical background of the income and wealth distribution in out time. Other very important added value of the book is that it has the richest collection of income and wealth data so far and analyzes its dynamics in the long run. ${ }^{27}$ Thomas Piketty puts forward a number of important paradigms about wealth distribution, where he defines that income inequalities of the 21 st century as "new forms of income inequality". ${ }^{28}$ According to this, in contrast to the income inequalities of the 19th century, today the wealth of the upper one to ten per cent of society comes mainly from its income and not from the inherited wealth. The question is, how does this relate to our topic? As an important feature of income inequality is that the income of private-sector executives grew dramatically, thus representing the group of first-generation millionaires. ${ }^{29}$

Piketty in the theory of the "Illusion of Marginal Productivity"draws the attention of the world to the fact that the most important cause of today's wage subsidies is the emergence and extreme growth of so-called "new salaried rich" social strata, which has not yet hindered anything. His theory focuses on a group of top executives with an annual income of between $\$ 300,000$ and $\$ 1$ Million (USD) per year, and as a result of his investigation, he claims that the individual productivity of senior executives in the United States is a merely subjective statement that can not be measured objectively in proportion to their income. Determining the income of managers is dependent on the decisions of individual and corporate "buddies". This is the so-called "cornyism". ${ }^{30}$ The income from external

${ }^{26}$ Tibor Nochta, “Ünnepi tanulmányok Kecskés László professzor 60. születésnapja tiszteletére”, A magánjogi menedzserfelelősségröl, (eds.: Nochta Tibor, Fabó Tibor, Márton Mária), Pécsi Tudományegyetem, Állam- és Jogtudományi Kar, Pécs, 2013, 484.

${ }^{27}$ Wojciech Kopczuk, "What we know about the Evolution of Top Wealth Shares int he United States?", Journal os Economic Perspective, 2015/29/1 47-66.

${ }^{28}$ James Pierson, "Background Facts", Inequality and Economic Policy, (eds.Tom Church, John B. Taylor- Christopher Miller), Hoover Press, 2015

${ }^{29}$ It is also important to point out that, in contrast to the general belief, in many societies, including in the United States, are not nearly as much egalitarian as we would think. In the USA an unprecedented explosion of inequalities began in the 1980s. All this undoubtedly contributed to the financial instability of their economy, and finally to the global economic crisis. See in: Daron Acemoglu, James A. Robinson, "The Rise and Decile of General Laws of Capitalism", Journal of Economic Perpectives- 2015/29/1 3-28. p.

${ }^{30}$ John H. Cochrane, "Why we care about inequality", Inequality and Economic Policy (eds. Tom Church, John B. Taylor, Christopher Miller), Hoover Press, 2015, 144-156. 
influences is called "pay for luck" money, which is not based on individual performance, but comes from external economic conditions, such as an increase in the market price of stock exchange shares. From all these it can be deducted that the responsible corporate governance unfortunately cannot emerge, or at least, does not want to prevail in all circumstances. ${ }^{31}$

To maximize profits, managers have a high level of autonomy, that is followed by the prescribtion of the adjusting unlimited liability rules based on civil law. Consequently, we can say that the management contract is a special - atypical employment contract that also contains civil law elements. ${ }^{32}$

Another important component of the employment of executive employees is the composition of the performance expectations of the manager, which is often quantified in indexes such as the market share of the company, the number of shareholders and the rate of profit growth. These indicators depend highly on the individual performance of the managers and therefore, to a large extent, determine the amount of the manager's salaries.

The salary package of the managers consists of the base wage, which is supplemented by several incentive remunerations, such as employee shares, performance bonuses, cars, and so on. With these additional payments, managers get interested in increasing the profitability of a company (for example, by becoming owners of the company), while being honored for the responsible work and their loyalty to the company and the owners. ${ }^{33}$ If we look at the trend regarding the salaries of the managers, it can be clearly stated that American managers obtain the highest income by far, which has only gained momentum over the last few decades. The trend in the payroll of managers is that determining their incomes is rather dependent on individual corporate leadership than relying on labor law rules. ${ }^{34}$ Another important

${ }^{31}$ Thomas Piketty, Capital in the twenty-first century, The Belknap Press of Harward University Press, London, 2014, 335.

32 Emese Törö, A köz és a versenyszférában megvalósuló vezetői jogállás kritikai elemzése, Ph.D. értekezés, 2005, 124-149.

${ }^{33}$ Defining the elements of manager payouts may vary, depending on the combination of these factors or the ratio of these factors. These differences are greatly influenced by culture of each country and the given organization. For US companies, performance-oriented organizational culture plays a greater role, and hence individual earnings-based pay is the foundation for corporate competitiveness. Americans, as it is coming from their culture, also need to highlight "superstars",", supermanagers", who constitute the upper ten per cent of the society. See in: Kevin J. Murphy, CEO Pay and Appointment, A Market-Based Explanation for Recent Trends. Amrican Economic Review, $2 / 2004$

${ }^{34}$ The position of the CEO including their wage bargain is determined by the group of corporate executives, the management. For this reason, there is a kind of close-to-close cooperation between the CEOs in order to re-elect each other as an executive, in order to establish high payment packages to each other regardless of their individual performance. See in: Jesse M. Fried, Pay without Performance: Overview of the Issues. Harvard Law School, Economics and Business Discussion Paper Series, 2005/4-10. 21-34. 
issuees are the positive extern effects on the income of managers. That is, the income of managers often does not increase as a result of their individual performance, but comes from external economic and financial actors that have a positive impact on the company's competitiveness. But we have seen several examples in recent times where corporate management has caused serious losses to the company, but despite all this, there has not been any way to curb the salaries of these executives. The case is well exemplified by the case of the CEO of Deutsche Telekom, whose salary was increased in an inverse proportion to the share price of the company's share, that represented almost a forty percent difference. ${ }^{35}$

Another issue regarding the amount of the salaries is the information asymmetry, that is, it is not completely clear what does it consist of. In fact, in many cases, when the salaries were disclosed, it turned out that the assumed managerial salaries constitute only a fraction of the actual payments, because wage packages include a several bonuses and benefits above the base wage. This situation can be improved a little if the companies would be obliged to disclose these payments as well or at least shareholders, as the owners, would know the exact amount the managers were rewarded, so they could exercise some sort of control over their pay rates. If it was found that the determination of the payments of the managers was unreasonably too generous regarding their payments, there would be the opportunity to apply labor law consequences towards the executives. The other problem is that shareholders generally do not have the information they require, or they are not able to judge how much does exactly the work of corporate executives worth. As a result, shareholders do not constitute a real limit for managers to determine their salary. Until the amount of wages is not disclosed, the proportion of wages will be higher than the proportion, since the limit will only be their own moral limit. Based on this, we can say that the increased publicity of information could help to improve the bargaining power of shareholders and would give an opportunity for the (international) comparsion of the manager salaries and for the development and establishment of a scheme system.

The other important economics theory emerging from the analysis of executives is the client-agent problem, indicating that the manager incentives are not working perfectly, also that the cost-effectiveness principle and the representation of shareholders' interests are not automatically met. This problem is closely related to the presence of information asymmetry.

Besides the fact that the disclosure of salariest and severance payments may cause several social tensions, it may result in social envy and class struggles. ${ }^{36}$ The soft law solutions outlined in the next point could take the edge of the social risks that would come with a drastical legal regulation.

\footnotetext{
${ }^{35}$ Emese Törő, 2005.

${ }^{36}$ Balázs Muraközy, Mennyi fixszel viccel? (A menedzserfizetések nyilvánosságáról), Magyar Narancs https://magyarnarancs.hu/publicisztika/murakozy_balazs_mennyi_fixszel_ viccel_a_menedzserfizetesek_nyilvanossagarol-52612, 27 Jan, 2017)
} 
By presenting the problems described above, we can clearly state that the relationship between today's large companies and their leaders needs to be changed based on economic interests. Contrary to this, there is a view that regulatory interventions shall not be included within the framework of the idea of market economy which would undermine the freedom of action of market participants. Therefore, the question should be examined whether on what level of legislation and how this should be regulated. Two main directions have been identified in the literature to solve the issue regarding the wages of corporate executives. ${ }^{37}$ One of the solutions proposed is to create and apply stricter regulatory standards that would more extensively and more effectively contribute to the responsible, transparent and traceable operation of the corporations. The other solution - in terms of legal regulations including specific legal guarantees - supports the expansion of shareholder rights and the increased accountability of corporate management. One of the two directions focuses on labor law regulation, while the other focuses on corporate law issues based on new approaches. In both cases, the starting point is that corporate management often does not serve the interests of the company, but rather its own short-term individual earning interests. ${ }^{38}$

As a new alternative, the regulation of the position and income of executive employees can be solved by calling on incentives outside the scope of labor law. As a solution we would like to outline an opportunity that is quicker and less deteriorating to labor law guarantees, and that is based both on the dispositive, deviation-empowering nature of the Labor Code and the possibility of applying soft law solutions in labor law. The rules governing the activities of executive employees may not only be established within the framework of an employment contract, nor it may be filled with content only by an agreement, but it may appear in the guidelines of company expectations of the decision-making body of the company. ${ }^{39}$

\section{EXAMINING THE THEORIES IN THE FOREFRONT OF LABOR LAW - SUPPORTING THE RECOGNITION OF MARKET DEMANDS - FROM THE VIEW OF EXECUTIVE EMPLOYEES}

Within the framework of labor law, the application of soft law ${ }^{40}$ - as a new regulatory instrument for labor law instruments - has become more intense in recent decades. Within the pronciples of labor law, soft law instruments shall be

\footnotetext{
${ }^{37}$ Jesse M. Fried op. cit.21-34. p.

${ }^{38}$ Tibor Várady, Kommunista piacgondolkodás, Beszélő Online, http://beszelo.c3.hu/cikkek/ kommunista-piacgondolkodas, (27, Jan, 2017.)

39 Tibor Nochta, 484.

${ }^{40}$ For more on soft law see: D. Đurđev, Soft Law in Europen Community Law, Collected papers - Novi Sad Faculty of Law, No. 1/2013, 104.
} 
used, as far as economical interests are concerned, in order to increase efficiency and efficiency, and regarding labor law, because of the dissatisfactory operation of statutory labor law regulations. Soft law solutions, even though they can not be attributed to binding legal instruments, have an indirect, quasi-legal relevance. ${ }^{41}$ Thus soft law sanctions can indirectly influence the behavior of market participants, individuals, through their moral, ethical, social, and cultural effect. Nevertheless, soft law instruments have a moral "regulatory" executing power and responsibility attitude is strong, but it has to be remarked that their enforceability is weaker compared to classical legal instruments. Exactly because of their temporary position, soft law instruments can be a hallway of classical legal instruments so that they later become classical legal instruments. Both soft law and classical law respond to societal challenges and needs. ${ }^{42}$ The advantage of soft legal instruments is that they do not require explicit state intervention, so they can respond more quickly and more reflexively to the changing environment, avoiding any possible legislative difficulties. Such alternative regulatory instruments are emerging on those areas in particular that are confronted with high resistance through the complexity of their area of concern. So soft law can fill the legal gaps between the ideal and the real situation. ${ }^{43}$

These new self-regulation mechanisms of labor law offer more market-friendly solutions and form a bridge between market economy and regulations of the state with normative power. ${ }^{44}$ In the literature, the term "light touch" is often used to indicate how hard law is affected by self-regulatory legal mechanisms. Soft law instruments basically build on the self-regulatory behaviors of the market parrticipants, offer far better solutions than the sanctions imposed by the state. Of course, soft law has many advantages but it has its "shady side" as well. Critical commentators include such negative factors as its potential destructive impact on legislation, infringements without any legal consequences, and o regulatory frameworks that are not clearly defined, thus undermining the regulatory and control powers of the state. ${ }^{45}$

Due to globalization trends, state sanctions do not often emerge sufficiently effective enough, so it is typical at the area of labor law that states provide a greater autonomy to the self-operation of the corporations. It is, on the one hand, because large companies that are present at the market are transnational, and their

\footnotetext{
${ }^{41}$ Simon Deakin, "The Idea of Labour Law", The Contribution of Labour Law to Economic and Human Development, (eds. Guy Davidov, Brian Langille) Oxford University Press 2011, 156-179.

${ }^{42}$ Attila Kun, A puha jog (soft law) szerepe és hatékonysága a munkajogban, Az új Munka Törvénykönyve apropóján, Pázmány Law Working Papers, 2012/41, 1-4

${ }^{43}$ Attila Kun, A munkajogi megfelelés ösztönzésének újszerü jogi eszköze, Budapest, 2014, L'Harmattan Kiadó, 9-19.

${ }^{44}$ S. Deakin, (2011a), 156-179.

${ }^{45}$ A. Kun, (2012a), 1-4
} 
economic influence is growing in an emerging way. On the other hand, states' restrictive, paternalistic actions are incompatible with the ideology of free competition and market economies. Henry Arthurs is the first to formulate paradigms about the relationship between labor law and soft law. According to Arthus, the self-regulating mechanisms of the market play a much greater role in the development of market relationships than in public involvement. ${ }^{46}$ Arthurs' theory leads us to Deakin's theory of the relationship between the market and the labor law. Deakin's defines three roles of labor law, the market-restricting, the market-correctional, and the market-rewriting. ${ }^{47}$

The "restrictive role" of labor law is based on the fact that labor law is ineffective in the economic sense, since the state intervenes into the relationship of the parties through it s legal sanctions in order to enforce the interests of employees. In this respect, the classical role of labor law is the decisive one, where hard law instruments are intended to ensure the balanced situation in the market. With the "market correctional function" of labor law, Deakin expresses the requirement for the state to intervene through the labor law to protect the market participant that has weaker bargaining power. According to the third category, labor law also has a "market-creating function" in relation to the market. In addition to hard legal instruments, new innovative soft law instruments in labor law may also appear in this function. In this respect, Deakin points out that both substantive legal norms and soft law instruments aim to create an effective regulatory system in response to social economic environmental challenges.

Sen also highlights - when emphasizing the importance of human capital as a motor of long-term development - that the development of economies should not be interpreted narrowly. According to Hayek, "exploration process" resembles economic growth as a process in which we can not know what's coming to us. ${ }^{48}$ The basis for this is to ensure the freedom of individuals. With this, we come to a contradiction that the state is doing the best for the economy to grow if it does not directly strive to increase people's income, but when it allows people to exercise their freedoms. And by this we get back to labor law as a function of the state to define institutional guarantees of employment. ${ }^{49}$ According to Sen, capitalism has to face challenges such as inequality. Solving these problems goes beyond the institutional system of capitalist market economies and raises the question, what new instruments should be used outside of the pure state sanctions. Sen expresses that people have the right to live a life they want. For this, however, fundamental

${ }^{46}$ Harry Arthurs, "The Idea of Labour Law”, Labour Law after Labour, (ed. Guy Davidov, Brian Langille), Oxford University Press 2011, 13-30.

${ }^{47}$ S. Deakin, (2011a), 156-179.

${ }^{48}$ Friedrich August von Hayek, A verseny mint felfedezö folyamat, Piac és szabadság, Budapest, 1995, 302-311.

${ }^{49}$ S. Deakin (2011a), 156-179. 
freedoms such as political, economic and civil liberties must be guaranteed by the state. Because guaranteeing these rights and their relationship is not negligible in any legal environment. For example, the differences between executive officers, that appear in labor law as well, result in not only economic inequalities but also - indirectly originating from economic inequalities -regarding fundamental rights, violating the principle of the fundamental principle of equal treatment in the long run.

Sen says that "Basic code of good business behaviour is a bit like oxygen: we take an interest in its presence only when it is absent." ${ }^{\text {" To }}$ The direct aim of the labor law regulations is to create harmony between market efficiency and social goals through the increase of the employment rates or in order to increase them. It seeks to promote all these goals, see e.g. Deakin's theory of market and labor relations, by keeping the legal regulatory frameworks, and besides, it would incorporate new legal instruments to regulate labor law in a way that would not pull behind economic development incentives, but would support the achievement of economic goals too. The drastic increase in the income of executive officers is also a market failure that is a symptom of many system weaknesses. In terms of the income management and the liability of the executive officers, companies should develop an organizational culture, that would not only formally but also regarding daily activities, would be able to achieve through its positive actions that unreasonably high salaries and severance payments would not be paid. Soft law instruments could be adequate instruments in order to avoid the failure of responsible corporate governances due to their moral saturations. By applying soft law instruments, executive officers would not feel that the enforcing mechanism of the state is limiting their freedom to determine their income by an agreement concluded within the conditions of a free market economy.

\section{EVALUATION OF THE LEGAL REGULATIONS IN THE LIGHT OF ECONOMIC EXPECTATIONS}

By connecting these principles to the legal liability, it can be stated that personal interests often play a much greater role in the operation of companies than the situations modeled by law, and overwrite written or unwritten legal and ethical rules. Assuming this operation, the invisible hand of Adam Smith that ensures the balance between markets does not exist, and the market failures constantly drawing the attention to a need for the direct and indirect regulatory role of the state.

As far as the executive officer is concerned, there is obviously a collateral relationship between (labor and civil) law and economics. As labor law affects

${ }^{50}$ Amartya Sen, A fejlödés mint szabadság, Európa Könyvkiadó, Budapest, 2003, 402. 
income inequalities through the rules of employment regarding executive employees, or civil law through the rules of operation of coroorations, institutional economics also has the effect on the creation of the framework of law.

The regulation of executive employees is required by principles independent of the ownership, that can prevail through soft law instruments of a responsible corporate expectation system. However, the expectations of the ownership, the shareholders and the interests of the company are not always the same. ${ }^{51}$ This conflict of interests can be solved with the principal-agent dilemma and the problem of asymmetric information from the point of view of economics, but the legitimate assurance of the interests of the legal person is not sufficiently ensured solely by publicity as a response, so the clarification of rules of liability is indispensable. Incorporating the Corporate Governance approach into the assessment of managerial and executive liability also presents this legal and social control element in addition to the specific legislation. In our view, therefore, keeping the employees of a managerial position within the scope of labor law allows to keep employee interests - and indirectly through the employer's interests - company requirements under guarantees. In addition to this, however, the establishment of more robust, even soft or hard law control of the establishment of income rules within the market is necessary for the operation of the legal entities. In our view, maintaining labor law ratios would also require stronger interconnection of liability relations and income regulations.

${ }^{51}$ Tibor Nochta also considers it the starting point of the liability of the managers, in: $\mathrm{T}$. Nochta, 485. 
Др Хенриет̄ J. Раб, ванредни ӥрофесор

Универзийей у Дебрецину

Правни факулиетеи

Катеиедра за йољойривредно ирраво, ирраво живойне средине и радно ираво rab.henriett@law.unideb.hu

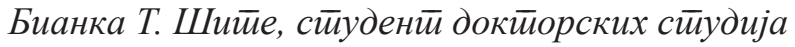

Универзитетеи у Дебрецину

Правни факулитети

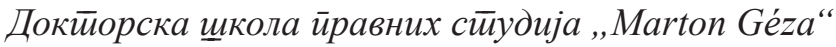

biankamathe@gmail.com

\section{Економски аспекти одговорности директора у процесу и организацији рада}

Сажейак: Неколико нових изазова који се йојављују иред тиржищйм рада и радним иравом узроковани су иревасходно друшиивеним и економским околностиима. Ове иромене делују зайраво сасвим ириродно: с једне стиране, иоолодавии имају своје економске иніиересе и друшимвени чиниоци у ироиесу рада ће се адайиирайи иррема новим оквирима зайошљаваға; с другее сіиране, иромене су иррисуйне и на стирани радника. Услови у којима раде каракиетище све већи стиеиен флексибилностии и дигитиализаџије, у суйройносиии са

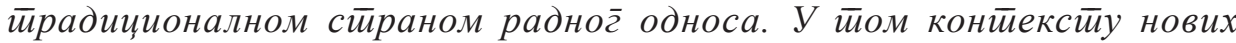
друшитвено-економских околносиии у којима се одвија рад, усредсредили смо се на йозииију дирекӣоа, јер у односу рада и кайийала они стиоје између йослодавиа и зайослених. Њихов задайак је деликайан, с обзиром да се од юих очекује да иситовремено и уирављају иррочесом рада, али и да размищ ьају као зайослени и да орг̄анизују рад на адекватиан начин. Из наведених разлог̄a

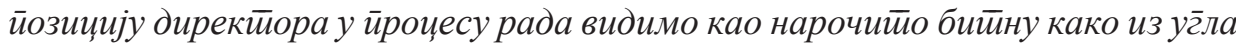
радног̄ иррава тиако и са економског̄ асиекӣа.

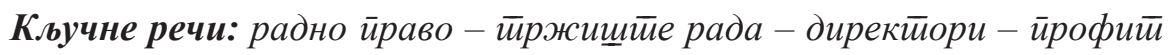
иослодавиа - радни однос

Датум пријема рада: 18.07.2018. 